Utah State University

DigitalCommons@USU

Plants, Soils and Climate Student Research

Plants, Soils, and Climate Student Works

$1-12-2015$

\title{
Critical Temperature for Sub-lethal Cold Injury of Strawberry Leaves
}

\author{
Tiffany L. Maughan \\ Utah State University \\ Brent Black \\ Utah State University \\ Daniel Drost \\ Utah State University
}

Follow this and additional works at: https://digitalcommons.usu.edu/psc_stures

Part of the Plant Sciences Commons

\section{Recommended Citation}

Maughan, Tiffany L.; Black, Brent; and Drost, Daniel, "Critical Temperature for Sub-lethal Cold Injury of Strawberry Leaves" (2015). Plants, Soils and Climate Student Research. Paper 1.

https://digitalcommons.usu.edu/psc_stures/1

This Other is brought to you for free and open access by the Plants, Soils, and Climate Student Works at DigitalCommons@USU. It has been accepted for inclusion in Plants, Soils and Climate Student Research by an authorized administrator of DigitalCommons@USU. For more information, please contact digitalcommons@usu.edu.

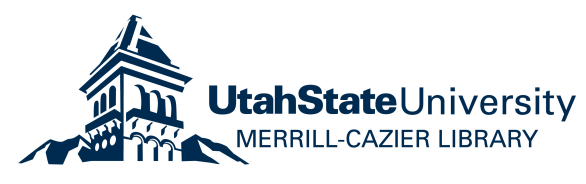


1 Critical Temperature for Sub-lethal Cold Injury of Strawberry Leaves

2

3 Tiffany L. Maughan, Brent L. Black ${ }^{1}$, Daniel Drost

4 Department of Plant, Soils, and Climate, Utah State University, 4820 Old Main Hill,

5 Logan, UT 84322 United States of America

6

$7 \quad$ Received for publication

8

9 This paper is a portion of a M.S. Thesis submitted by T. Maughan.

10

11

12 Disclaimer: Use of trade names does not imply an endorsement of the products named or

13 criticism of similar ones not named.

14

15 'Corresponding author: brent.black@usu.edu, 435-797-2174

16

17 
18 Abstract. Freezing temperatures are a major limitation to strawberry production in

19 temperate regions, and protected-cultivation strategies such as the use of tunnels and row

20 covers are used to minimize this limitation. In order to optimize management under

21 protected cultivation, it is necessary to understand the damage thresholds for strawberry

22 plant tissues. The effects of freezing temperatures $\left(-3,-5\right.$, and $\left.-7{ }^{\circ} \mathrm{C}\right)$ on leaf $\mathrm{CO}_{2}$

23 assimilation were evaluated on 'Chandler', 'Seascape' and 'Jewel' strawberry (Fragaria

$24 \times$ ananassa). Growth chambers were used to expose plants to freezing temperatures

25 under carefully defined conditions. Net assimilation was then measured on the cold-

26 exposed leaves, after the plants had been returned to $10{ }^{\circ} \mathrm{C}$. Exposure to $-3{ }^{\circ} \mathrm{C}$ did not

27 significantly reduce $\mathrm{CO}_{2}$ assimilation when compared to plants maintained at $10{ }^{\circ} \mathrm{C} \mathrm{d} / 5$

$28{ }^{\circ} \mathrm{C}$ night. However, leaves exposed to $-5{ }^{\circ} \mathrm{C}$ for one night had a net $\mathrm{CO}_{2}$ assimilation rate

29 that was $49 \%$ of the control. When leaves were first exposed to a conditioning night of -3

$30{ }^{\circ} \mathrm{C}$ and then exposed to $-5{ }^{\circ} \mathrm{C}$ the net assimilation rate was $62 \%$ of the untreated control.

31 Repeated exposure to -5 or $-7{ }^{\circ} \mathrm{C}$ night temperatures resulted in a further decrease in net

32 assimilation after each successive exposure. Leaves exposed to $-7{ }^{\circ} \mathrm{C}$ for one night had a

33 net assimilation rate of $6 \%$ of the control. Leaves exposed to $-5{ }^{\circ} \mathrm{C}$ or $-7{ }^{\circ} \mathrm{C}$ did not show

34 any recovery over a 28 -d monitoring period. There was no significant difference among

35 cultivars in the sensitivity of leaves to cold temperatures. These results indicate that

36 protected cultivation systems should be managed to maintain strawberry leaf

37 temperatures above $-5{ }^{\circ} \mathrm{C}$ in order to preserve full photosynthetic activity of existing

38 leaves which would extend the growing season of the crop.

40 Keywords. Cold hardiness, photosynthesis, carbon assimilation, recovery, Fragaria $\times$

\section{1 ananassa}




\section{Introduction}

Strawberries are produced in areas ranging from mild maritime to severe temperate continental climates. The plants are remarkably adaptable to a wide range of conditions and growing systems (Darrow, 1966). Despite this adaptability, temperature is a major limiting factor in production. Plant growth responds predictably to temperature. For strawberry, baseline temperature for growth is just above freezing (Galletta and Himmelrick, 1990), with growth rates increasing with temperature to an optimum of 20 to $26{ }^{\circ} \mathrm{C}$ (Darrow, 1966). Growth slows dramatically above the optimum temperature with higher temperatures eventually resulting in tissue necrosis (Carlen et al., 2009; Hancock, 1999).

Strawberry plants acclimate to cold conditions and can survive sub-freezing temperatures by tolerating ice formation in crown tissues. This is accomplished by water moving from within the cell to outside the cell to form extracellular ice (Hancock, 1999; Koehler et al., 2012; Warmund, 1993). Significant work has been done to assess cold temperature damage on crowns and inflorescences. Crowns have been found to be severely injured at $-9{ }^{\circ} \mathrm{C}$ when unprotected (Galletta and Himmelrick, 1990; Nestby and Bjorgum, 1999; Warmund, 1993) and killed at about $-12{ }^{\circ} \mathrm{C}$ when acclimated, with some variation by cultivar (Darrow, 1966). Once inflorescences begin to expand in the spring, floral organs are susceptible to damage at $-1{ }^{\circ} \mathrm{C}$ (Hummel and Moore, 1997; Maas, 1998). Although somewhat limited, work has also been done to assess cold temperature damage on leaves. Even in relatively cold temperate regions, leaves may remain green throughout the winter months. However, it is not known whether these leaves maintain photosynthetic activity and contribute to continued plant growth once environmental conditions improve. Research on cold temperature damage in strawberry leaves has been conducted on detached leaves or excised leaf disks. Detached leaves sustain significant 
68 damage, as assessed by solute leakage, when exposed to temperatures between -5 and -12

$69{ }^{\circ} \mathrm{C}$ (O’Neill et al., 1981; Owens et al., 2002). Working with detached leaves does not

70 allow determination of tissue recovery from cold temperature damage. We are unaware

71 of published reports investigating photosynthetic response of attached leaves to freezing

72 temperatures.

73 The bulk of commercial strawberry production in North America occurs in mild

74 maritime climates where temperatures rarely drop to levels that would damage leaves.

75 However, small-scale production continues throughout North America to target the

76 increasing demand for locally grown food. In regions with cold fall and winter

77 temperatures and frequent spring frost events, growing strawberries under protected

78 cultivation such as high tunnels, low tunnels, or floating row covers is becoming more

79 common (Fernandez, 2001; Himmelrick et al., 2001; Rowley, 2010). Since protected

80 cultivation involves actively managing temperature, understanding the critical

81 temperature thresholds for plant injury is essential to developing optimized management

82 strategies. Knowing the temperature at which the leaves lose photosynthetic capacity

83 will provide guidelines in employing and managing these protected-cultivation strategies.

84 In this study we investigated the effect of cold temperature exposure on leaf injury and

85 subsequent recovery, as determined by photosynthetic activity.

86 2. Materials and Methods

872.1 Plant production. Cold-stored dormant plants were obtained from a commercial

88 nursery (Lassen Canyon Nursery, Redding, CA). The cultivars 'Chandler', 'Seascape'

89 and 'Jewel' were selected to represent adaptation to different production systems in the

90 United States, namely California June-bearing and day neutral production systems, and

91 Northeast production. Plants were established in $2.0 \mathrm{dm}^{3}$ containers of soilless media

92 (1:1:1 peat moss, vermiculite, and perlite) and fertilized three to four times a week with a 
water soluble 20N-10P-20K fertilizer diluted to $100 \mathrm{ppm}$. Plants were grown under

94 greenhouse conditions of $22{ }^{\circ} \mathrm{C} \mathrm{d} / 16{ }^{\circ} \mathrm{C}$ night, with a day length of $14 \mathrm{~h}$ maintained with

95 supplemental light from metal-halide lamps until five fully expanded trifoliate leaves

96 were present (typically 4 weeks), and then used for the specific experiments.

97 Inflorescences were removed upon emergence.

982.2 Freezing tests. Prior to the beginning of freeze tests, plants were acclimated for $7 \mathrm{~d}$ in 99 a walk-in growth chamber (EGC Plant Growth Chamber; Chagrin, $\mathrm{OH}$ ) at $10^{\circ} \mathrm{C} \mathrm{d} / 5^{\circ} \mathrm{C}$ 100 night temperatures, with a light period of $9 \mathrm{~h}$, at a light intensity of 200 to $250 \mu \mathrm{mol} \cdot \mathrm{m}^{-}$ $10 \mathrm{~L}^{2} \cdot \mathrm{s}^{-1}$. Once acclimated, individual plants were selected for uniformity and transferred to 102 an environmental test chamber (Tenney Model TUJR, Winona, MN) for exposure to one 103 of the freezing regimes. The test chamber's performance was verified using 104 thermocouples connected to a CR 1000 data logger (Campbell Scientific, Logan, UT). 105 The freezing cycle was programmed to simulate a high tunnel during a cold night in the 106 winter, where temperatures regularly fall below $0{ }^{\circ} \mathrm{C}$ (Maughan, 2013). Briefly, as lights 107 turned off in the growth chamber, a selected plant was moved to the environmental test 108 chamber. Pots were placed in an insulated box to prevent freezing of the roots and crown 109 during the freezing cycle. Air temperature was then held at $5{ }^{\circ} \mathrm{C}$ for $4.5 \mathrm{~h}$, and then 110 slowly decreased to the target freezing temperature over $3.5 \mathrm{~h}$. Once the target freezing 111 temperature was reached, it was held for $4 \mathrm{~h}$, and then the chamber temperature gradually 112 increased to $5^{\circ} \mathrm{C}$ over a 3 -h period. The plant was then returned to the growth chamber, 113 where leaf injury was determined based on net $\mathrm{CO}_{2}$ assimilation rate $(A)$, using a portable 114 infrared gas analyzer (LI-6400, Li-Cor; Lincoln, NE) equipped with a LED supplemental 115 light head that supplied $200 \mu \mathrm{mol} \cdot \mathrm{m}^{-2} \cdot \mathrm{s}^{-1}$ light. Injury assessment was carried out on the 116 youngest fully expanded leaf and data recorded continuously for $4 \mathrm{~h}$. The controls were 
117 untreated plants of the same developmental stage, kept in the growth chamber at a

118 constant $10{ }^{\circ} \mathrm{C} \mathrm{d} / 5^{\circ} \mathrm{C}$ night temperature regime.

1192.3 Temperature step-down. Selected plants from each cultivar ('Chandler', 'Seascape’

120 and 'Jewel') were exposed to successively lower temperatures $\left(-3,-5,-7,-9\right.$, and $\left.-11^{\circ} \mathrm{C}\right)$

121 in the environmental test chamber on five consecutive nights. Each morning the plant was

122 moved back to the growth chamber and leaf gas exchange was monitored for $4 \mathrm{~h}$ to

123 determine $A$. The experiment was repeated on four replicate plants of each cultivar.

1242.4 Repeated freeze. Acclimated 'Chandler' plants were subjected to the same target

125 temperature, $\left(-3,-5\right.$, or $\left.-7^{\circ} \mathrm{C}\right)$ for three consecutive nights, and $A$ monitored between

126 freeze cycles for $4 \mathrm{~h}$ immediately upon removal from the test chamber. The -5 and $-7^{\circ} \mathrm{C}$

127 trials were replicated five times and the $-3{ }^{\circ} \mathrm{C}$ trial was replicated twice.

2.5'Conditioned' repeat freeze. Acclimated 'Chandler' plants were subjected to a

129 conditioning night of $-3{ }^{\circ} \mathrm{C}$, followed by three consecutive nights of $-5^{\circ} \mathrm{C}$ using the

130 methods described above. Gas exchange was monitored for $4 \mathrm{~h}$ periods in the morning

131 between each freezing cycle. This trial was replicated three times. In a second trial that

132 was also replicated 3 times, 'Chandler' and 'Seascape' plants were conditioned for one

133 night of $-3^{\circ} \mathrm{C}$, followed by six consecutive nights of $-5^{\circ} \mathrm{C}$.

1342.6 Recovery. On four consecutive nights, two acclimated plants were exposed to either -

1355 or $-7^{\circ} \mathrm{C}$ as described above, and then returned to the growth chamber. After the fourth

136 night, leaf $A$ was measured every $30 \mathrm{~s}$ for $15 \mathrm{~min}$ on the youngest fully expanded leaf and

137 the second-oldest leaf on each of these plants. Measurements were repeated every $4 \mathrm{~d}$

138 until $28 \mathrm{~d}$ after initial exposure. Measured leaves were tagged to ensure repeated

139 measurement on the same leaf. This trial was replicated four times.

1402.7 Field-grown comparison. Fall-planted 'Chandler' and 'Seascape' plants from the

141 Greenville Research Farm in North Logan, UT (41.735 N latitude and 1455 m elevation) 
142 were dug on 1 March, 2013, just as they were breaking winter dormancy. Two replicate

143 plants with overwintering leaves still intact were removed from each treatment and

144 transplanted into $2.0 \mathrm{dm}^{3}$ pots. Plants were from another experiment and grown in three

145 different treatments, an unprotected outdoor field, under high tunnel protection, or under

146 a low tunnel within a high tunnel (Maughan, 2013). Potted plants were moved to the

$14710^{\circ} \mathrm{C} \mathrm{d} / 5^{\circ} \mathrm{C}$ night growth chamber (11 h day/ $13 \mathrm{~h}$ night, mimicking spring conditions $)$,

148 and $A$ was measured on over-wintering leaves approximately $3 \mathrm{~h}$ after being brought into

149 the growth chamber.

1502.8 Statistical analysis. Data were subjected to analysis of variance (ANOVA) by

151 standard procedures using the PROC REGWQ in SAS (version 9.3, SAS Institute, Cary,

152 NC). Each series of experiments were analyzed as completely randomized designs. The

153 step-down trial was analyzed using a non-linear regression to determine the $\mathrm{LT}_{50}$

154 (temperature resulting in 50\% loss of $A$ activity). A sigmoid 3 parameter curve was fit to 155 the data $\left(\mathrm{f}=\mathrm{a} /(1+\exp (-(\mathrm{x}-\mathrm{x} 0)) / \mathrm{b})\right.$ where $\mathrm{a}=\max$ value, $\mathrm{b}=$ slope at $\mathrm{x} 0$ and $\mathrm{x} 0=\mathrm{LT}_{50}$,

156 using Sigma Plot (Version 10.0, Systat Software, San Jose, CA).The assimilation

157 recovery trial was analyzed as a repeated measures design using orthogonal contrast

158 statements in PROC GLM. The cultivar comparison experiments were analyzed as a

159 cultivar by temperature factorial. Means separation was by Tukey-Kramer at the 0.05

160 level of significance.

161 3. Results

1623.1 Temperature step-down. Strawberry leaves were exposed to incrementally lower

163 temperatures for five consecutive nights, with $A$ measured the day after each exposure.

164 Plants exposed to $-3{ }^{\circ} \mathrm{C}$ for $4 \mathrm{~h}$ had $A$ rates that were not significantly different from

165 control plants. As plants were exposed to colder temperatures, there was a significant

166 reduction in $A$ with each successively colder temperature (Fig. 1). There was no 
167 difference in $A$ response among the three cultivars tested (Chandler, Seascape, and Jewel;

$168 P=0.11)$. Nonlinear regression with data combined from all cultivars predicted an $\mathrm{LT}_{50}$

169 of $-5.3{ }^{\circ} \mathrm{C}$. The predicted $\mathrm{LT}_{50}$ for 'Chandler', 'Seascape' and 'Jewel' was $-5.80 \pm 0.33$

$170{ }^{\circ} \mathrm{C},-5.45 \pm 0.35{ }^{\circ} \mathrm{C}$ and $-5.07 \pm 0.16{ }^{\circ} \mathrm{C}$, respectively.

171

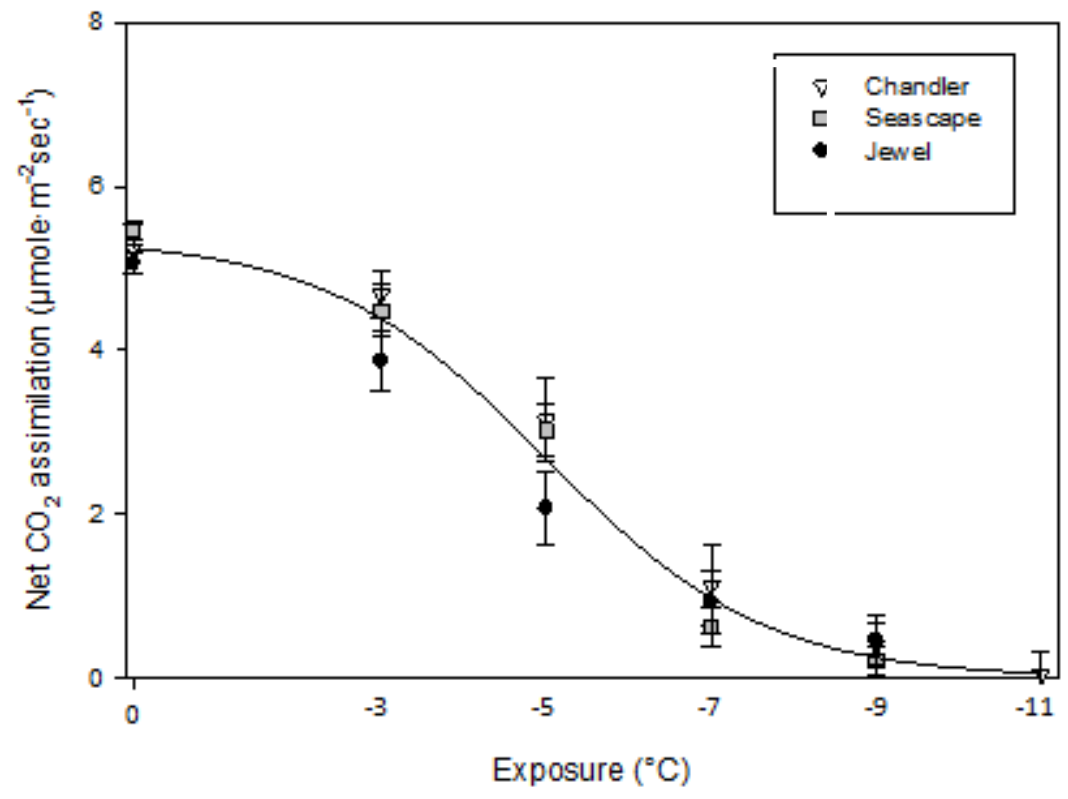

172

173 Figure 1. Extinction curve showing the effect of exposure to progressively colder

174 temperatures on net $\mathrm{CO}_{2}$ assimilation. Symbols represent mean for individual

175 cultivars \pm standard error $(\mathrm{N}=4)$.

1763.2 Repeat freeze. Leaves of the cultivar 'Chandler' exposed to three consecutive cycles

177 of $-3{ }^{\circ} \mathrm{C}$ had the same leaf $A$ as untreated controls. Leaves exposed to consecutive nights

178 of $-5{ }^{\circ} \mathrm{C}$ had $A$ rates of $49 \%, 26 \%$ and $10 \%$, respectively, which was a statistically

179 significant reduction in $A$ after each successive night. Plants exposed to $-7^{\circ} \mathrm{C}$ had $A$ rates

180 that were not significantly different from zero after a single night exposure (data not

181 shown). 
1823.3 'Conditioned' repeat freeze. Interestingly, 'Chandler' plants exposed to a single night 183 of $-5{ }^{\circ} \mathrm{C}$ in the repeat freeze experiment showed lower leaf $A$ than plants first exposed to -

$1843{ }^{\circ} \mathrm{C}$, then exposed to $-5^{\circ} \mathrm{C}$ the following night as seen in the step-down experiment.

185 Expressed as a percent of the untreated control, $A$ was $49 \%$ after a single night exposure

186 to $-5{ }^{\circ} \mathrm{C}$, compared to $89 \%$ of control after $-3{ }^{\circ} \mathrm{C}$ and then $-5{ }^{\circ} \mathrm{C}$ (Fig. 1). Similarly, $A$ was

187 reduced more by one night of $-7^{\circ} \mathrm{C}\left(\mathrm{A} ; 6 \%\right.$ of control) than when exposed to $-7^{\circ} \mathrm{C}(\mathrm{A}$;

$18862 \%$ of control) in the step-down study. These results suggest that previous exposure to

189 sub-zero temperatures improves subsequent cold temperature tolerance.

190 To test this hypothesis, plants were exposed to a single night of $-3^{\circ} \mathrm{C}$ followed by

191 three nights of $-5^{\circ} \mathrm{C}$ and compared to plants that received three nights of $-5{ }^{\circ} \mathrm{C}$ without

192 the $-3{ }^{\circ} \mathrm{C}$ conditioning (Table 1 ). Conditioning followed by a single night of $-5^{\circ} \mathrm{C}$ resulted 193 in a $38 \%$ reduction in $A$, which was significantly different from the $51 \%$ reduction in the

194 non-conditioned plants. However, $A$ capacity continued to decrease linearly with each 195 successive night of cold exposure in both conditioned and non-conditioned plants. For 196 non-conditioned plants, $A$ rate after day 3 was significantly different from $A$ rate after day $1971(P<0.001)$. Although the $A$ rates also trended downward for the conditioned plants, 198 differences between the first and third exposure were not statistically significant at $P<$ 1990.05. 
Table 1. The effect of a single conditioning night at $3^{\circ} \mathrm{C}$ on leaf photosynthetic activity of 'Chandler' strawberry over three nights of $-5^{\circ} \mathrm{C}$. Values are percent of control plants kept at $10{ }^{\circ} \mathrm{C} \mathrm{d} / 5^{\circ} \mathrm{C}$ night.

\begin{tabular}{lccc}
\hline Conditioning & \multicolumn{3}{c}{ Day } \\
\cline { 2 - 4 } & 1 & 2 & 3 \\
\hline \multirow{2}{*}{ None } & (\% of control $)$ \\
$-3 \mathrm{a}^{\mathrm{a}}$ & $27 \mathrm{a}$ & $10 \mathrm{a}$ \\
& $62 \mathrm{~b}$ & $46 \mathrm{~b}$ & $42 \mathrm{~b}$ \\
\hline
\end{tabular}

${ }^{\mathrm{a}}$ Values within a column followed by the same letter are not significant at $P \leq 0.05$.

201

2023.4 Recovery over time. Due to the level of damage observed from exposure to -5 and -7

$203{ }^{\circ} \mathrm{C}$, experiments were conducted to determine the ability of leaves to recover from a 204 single exposure to $-5^{\circ} \mathrm{C}$. For all three cultivars ('Chandler', 'Seascape' and 'Jewel'), 205 leaves exposed to $-5^{\circ} \mathrm{C}$ sustained less damage, as measured by $A$ capacity, than those 206 exposed to $-7^{\circ} \mathrm{C}$. Although leaf $A$ was monitored for $28 \mathrm{~d}$, there was no statistically 207 significant increase in $A$ for any of the cultivars for young or old leaves over that period 208 (Fig. 2). 

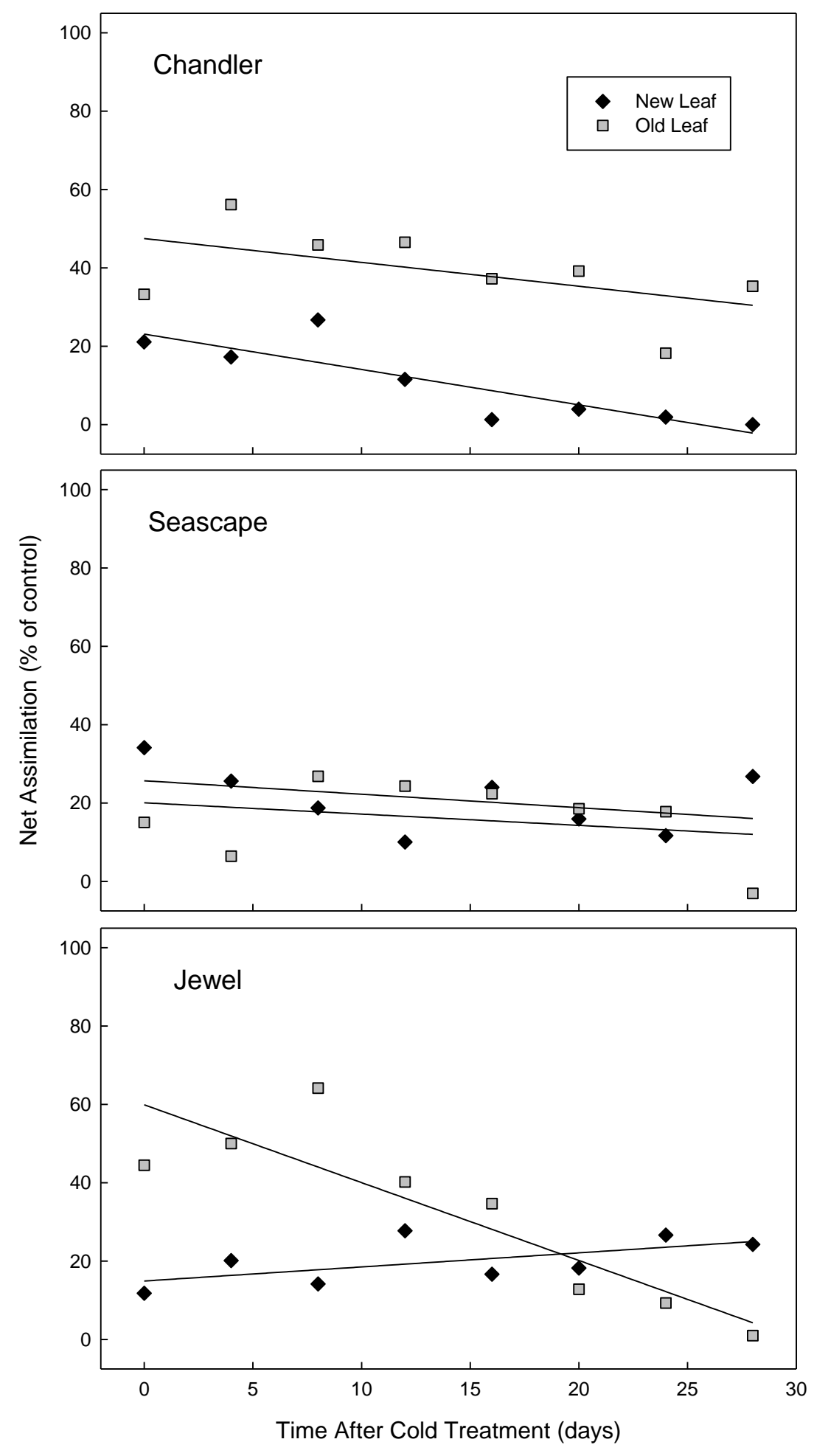

230

231 Figure 2. Long-term effect of a single night of $-5^{\circ} \mathrm{C}$ exposure on net

232 assimilation, expressed as \% of untreated control. Data points are the mean of 4

233 replicate plants. None of the slopes were significantly greater than zero,

234 indicating no recovery over $28 \mathrm{~d}$. 
2353.5 Field-grown comparison plants. 'Chandler' and 'Seascape' strawberries grown under 236 unprotected field conditions had significantly lower $A$ than plants grown with the

237 protection of a high tunnel $(P=0.0003$, Table 2$)$. The additional protection provided by a 238 low tunnel within the high tunnel did not improve photosynthetic rate over a high tunnel 239 alone $(P=0.086)$, although high tunnel + low tunnel managed plants had slightly higher $240 A$, which corresponds to warmer mid-winter temperatures recorded in this treatment 241 (Maughan, 2013). There was no statistically significant difference between the two 242 cultivars evaluated $(P=0.55)$. Unprotected field grown, high tunnel, and high tunnel + 243 low tunnel grown plants had photosynthetic rates that were 88, 66 and 59\% lower, 244 respectively, than the greenhouse-grown control plants held in a growth chamber at $10{ }^{\circ} \mathrm{C}$ $245 \mathrm{~d} / 5^{\circ} \mathrm{C}$ night (Table 2$)$.

Table 2. Net $\mathrm{CO}_{2}$ assimilation rate $(A)$ among field-grown, high tunnel (HT) and low tunnel (LT) strawberry plants, and greenhouse-grown plants kept at $10{ }^{\circ} \mathrm{C} \mathrm{d} / 5^{\circ} \mathrm{C}$ night.

\begin{tabular}{|c|c|c|c|c|}
\hline \multirow[t]{2}{*}{ Cultivar } & \multicolumn{4}{|c|}{ Treatment } \\
\hline & Greenhouse & Field & HT & $\mathrm{HT}+\mathrm{LT}$ \\
\hline Chandler & 9.23 & $0.59 b$ & $3.08 \mathrm{a}$ & $3.97 \mathrm{a}$ \\
\hline Seascape & 8.76 & $1.64 b$ & $3.07 \mathrm{a}$ & $3.39 \mathrm{a}$ \\
\hline \multicolumn{2}{|c|}{ Analysis of Variance } & $P$ & & \\
\hline \multicolumn{2}{|c|}{ Treatment } & $<0.001$ & & \\
\hline \multicolumn{2}{|c|}{ Cultivar } & 0.548 & & \\
\hline
\end{tabular}

Numbers within a row followed by the same letter are not significantly different. Greenhouse plant values listed as a reference and are not included in statistical analysis. 


\section{Discussion}

Strawberries have been successfully produced in the Intermountain West using a

249 combination of high tunnels and low tunnels (Maughan, 2013; Rowley et al., 2010). In

250 these high tunnel systems, strawberries are planted in the fall and harvested very early the

251 following spring. Fall growth is important for high yields, as plants need to develop

252 adequate roots, branch crowns and flower buds. Plant development continues in the

253 tunnels during the winter due to adequate growing temperatures, despite low light levels.

254 Early fall and late spring frosts are common throughout the Intermountain West and these

255 conditions may contribute to lower productivity. Therefore, providing minimum

256 temperature thresholds will help growers make better decisions regarding temperature

257 management within the tunnels, including when supplemental heat might be justified

258 (Maughan, 2013).

259

Work by O’Neill et al. (1981) and Owens et al. (2002) found that significant

260 damage (measured by solute leakage) occurred when excised leaf disks were exposed to

261 temperatures between -5 and $-12{ }^{\circ} \mathrm{C}$. Our data with intact leaves attached to the plant

262 supports these findings. We found a significant drop in $A$ rate after a single night

263 exposure to $-5^{\circ} \mathrm{C}$, with a nearly complete loss of $A$ capacity after multiple exposures to -

$2645{ }^{\circ} \mathrm{C}$, or a single night of exposure to $-9^{\circ} \mathrm{C}$. Leaves exposed to these cold conditions did

265 not recover and thus would not contribute to subsequent plant growth. Although $\mathrm{LT}_{50}$ is

266 traditionally used to describe the temperature at which half of the plants die, in this study

$267 \mathrm{LT}_{50}$ was used in reference to the temperature at which there was a $50 \%$ reduction of the

268 net $\mathrm{CO}_{2}$ assimilation.

269 The effect of a single conditioning night at $-3{ }^{\circ} \mathrm{C}$ on $A$ with subsequent exposure

270 to colder temperatures was particularly interesting. It is generally accepted that

271 strawberry plants acclimate to cold temperatures, typically this acclimation is 
272 accomplished within 7 days (Darrow, 1966). Based on our results from the step-down

273 and repeat freeze experiments, we found some acclimation occurs after only one night

274 exposure to freezing temperatures. However, even with a conditioning night, $A$ activity

275 continues to decline with repeated exposure to sub-critical temperatures.

276 The lack of recovery in photosynthetic capacity after exposure to damaging cold

277 temperatures suggests that plants with freezing damage to the leaves would recover by

278 producing new leaves to support further growth, rather than repairing damaged leaves.

279 Therefore, to gain the most benefit from protected cultivation, canopy temperatures

280 should remain above $-5^{\circ} \mathrm{C}$. While high tunnels have been shown to have air temperature

281 significantly warmer than outside air during the day (Wien, 2009), additional heating may

282 be warranted at night when air temperature differences are not as great. The analysis of

283 the field-grown plants further indicates benefits of using protected cultivation since $A$

284 rates of leaves grown in high tunnels were significantly higher than those kept outdoors.

285 Growth chamber studies may underestimate the potential damage that occurs to

286 leaves in the field, as none of the leaves in the growth chambers were simultaneously

287 exposed to extreme cold and bright light conditions, as would be the case at sunrise when

288 the air temperatures are often the coldest. Theoretically, freezing temperatures in

289 conjunction with high light levels would be more damaging than gradually warming

290 frozen leaves in darkness prior to light exposure, as measured in this study. This is due to

291 an increased susceptibility to light stress at low temperatures as seen by Powles et al.

292 (1983). As this is a common condition of field or tunnel grown strawberries in the

293 Intermountain West, a more complete understanding of leaf damage would require

294 additional investigation of the effect of freezing temperatures coupled with exposure to

295 sunlight. Even with the theoretically increased damage of both light exposure and

296 freezing temperatures, plants under at least high tunnels had an average of a 400\% 
297 increase in photosynthetic activity over unprotected plants where temperatures dropped

298 below $-5{ }^{\circ} \mathrm{C}$ on multiple occasions.

299 5. Conclusion

300 In conclusion, leaves exposed to $-3{ }^{\circ} \mathrm{C}$ for $4 \mathrm{~h}$ did not experience a significant reduction

301 in net $\mathrm{CO}_{2}$ assimilation. Regression analysis indicated the $\mathrm{LT}_{50}$ was between -5 and $-6{ }^{\circ} \mathrm{C}$

302 for all cultivars tested (Fig. 1), with 'Chandler', 'Seascape' and 'Jewel' being $-5.80{ }^{\circ} \mathrm{C}$, -

$3035.45{ }^{\circ} \mathrm{C}$ and $-5.07{ }^{\circ} \mathrm{C}$, respectively. Exposure to $-3{ }^{\circ} \mathrm{C}$ before exposure to -5 and $-7{ }^{\circ} \mathrm{C}$

304 improved cold temperature tolerance of leaves. When leaves were exposed to -5 and -7

$305{ }^{\circ} \mathrm{C}$ without conditioning exposure to freezing temperatures, more severe damage was

306 observed, as indicated by a significant reduction in photosynthesis. Furthermore, young

307 and old leaves exposed to a single night of $-5{ }^{\circ} \mathrm{C}$ did not recover lost photosynthetic

308 activity even after $28 \mathrm{~d}$ at $10{ }^{\circ} \mathrm{C}$ d $/ 5^{\circ} \mathrm{C}$ night. Strawberry plants in protected cultivation

309 systems should be kept above $-5^{\circ} \mathrm{C}$ to minimize leaf damage and promote continued

310 growth.

311 6. Acknowledgements

312 The authors thank James Frisby (Utah State University) and Elizabeth Gordon (Li-Cor

313 Biosciences) for technical assistance. Funding was provided by grants from the research

314 foundation of the North American Strawberry Growers Association, the Utah Dept. of

315 Agriculture and Food Specialty Crop Block Grant Program and by the Utah Agricultural

316 Experiment Station, Utah State University, and approved as journal paper number 8675.

\section{7. Literature Cited}

318 Carlen, C., A.M. Potel and A. Ancay. 2009. Photosynthetic response of strawberry leaves

319 to changing temperatures. Acta Hort. 838: 73-76.

320 Darrow, G.M. 1966. Climate and the strawberry, p. 355-365. In: The Strawberry. Holt, 321 Rinehart and Winston, New York, NY. 
322 Fernandez, G.E. 2001. Fall-applied rowcovers enhance yield in plasticulture strawberries.

323 HortTechnology 11(3): 440-444.

324 Galletta, G.J. and D.G. Himmelrick. 1990. Strawberry Management, p. 83-156. In: Small

325 fruit crop management. Prentice Hall, Englewood Cliffs, NJ.

326 Hancock, J.F. 1999. Structural and development physiology, p. 90-110. In: Strawberries.

327 CABI Publishing, New York, NY.

328 Himmelrick, D.G., F.M. Woods, B.S. Wilkins and J.A. Pitts. 2001. Use of floating row

329 covers in annual hill plasticulture strawberries. Small Fruits Rev. 1(4): 63-71.

330 Hummel, R.L. and P.P. Moore. 1997. Freeze resistance of Pacific Northwest strawberry

331 flowers. J. Am. Soc. Hortic. Sci. 122(2): 179-182.

332 Koehler, G., R. C. Wilson, J. V. Goodpaster, A. Sonsteby, X. Lai, F.A. Witzmann, J.

333 You, J. Rohloff, S.K. Randall, and M. Alsheikh. 2012. Proteomic study of low-

334 temperature responses in strawberry cultivars (Fragaria $\times$ ananassa) that differ in cold

335 tolerance. Plant Physiol. 159: 1787-1805.

336 Maas, J.L. 1998. Compendium of strawberry diseases. $2^{\text {nd }}$ edition. American

337 Phytopathiological Society. APS Press, St. Paul, MN.

338 Maughan, T.L. 2013. Optimizing systems for cold-climate strawberry production. MS

339 Thesis. Utah State University. Logan, UT.

340 Nestby, R. and R. Bjorgum. 1999. Freeze injury to strawberry plants as evaluated by

341 crown tissue browning, regrowth and yield parameters. Scientia Hortic. 81(3):321-329.

342 O'Neill, S.D., D.A. Priestley and B.F. Chabot. 1981. Temperature and aging effects on

343 leaf membranes of a cold hardy perennial, Fragaria virginiana. Plant Physiol. 68: 1409-

3441415. 
345 Owens, C.L., M.F. Thomashow, J.F. Hancock and A.F. Iezzoni. 2002. CBF1 orthologs in 346 sour cherry and strawberry and the heterologous expression of $C B F 1$ in strawberry. J.

347 Am. Soc. Hortic. Sci. 127(4): 489-494.

348 Powles, S.B., J. A. Berry and O. Bjorkman. 1983. Interaction between light and chilling

349 temperature on the inhibition of photosynthesis in chilling-sensitive plants. Plant, Cell

350 and Environ. 6: 117-123.

351 Rowley, D. R. 2010. Season extension of strawberry and raspberry production using high

352 tunnels. MS Thesis. Utah State University. Logan, Utah.

353 Rowley, D., B.L. Black and D. Drost. 2010. Early-season extension using June-bearing

354 'Chandler' strawberry in high-elevation high tunnels. HortScience 45(10): 1464-1469.

355 Warmund, M.R. 1993. Ice distribution in 'Earliglow' strawberry crowns and tissue

356 recovery following extracellular freezing. J. Amer. Soc. Hort. Sci. 118(5): 644-648.

357 Wien, H.C. 2009. Microenvironmental variations within high tunnels. HortScience.

$358 \quad 44: 235-238$. 